\title{
A Petrified Forest \\ On Unga Island, Alaska
}

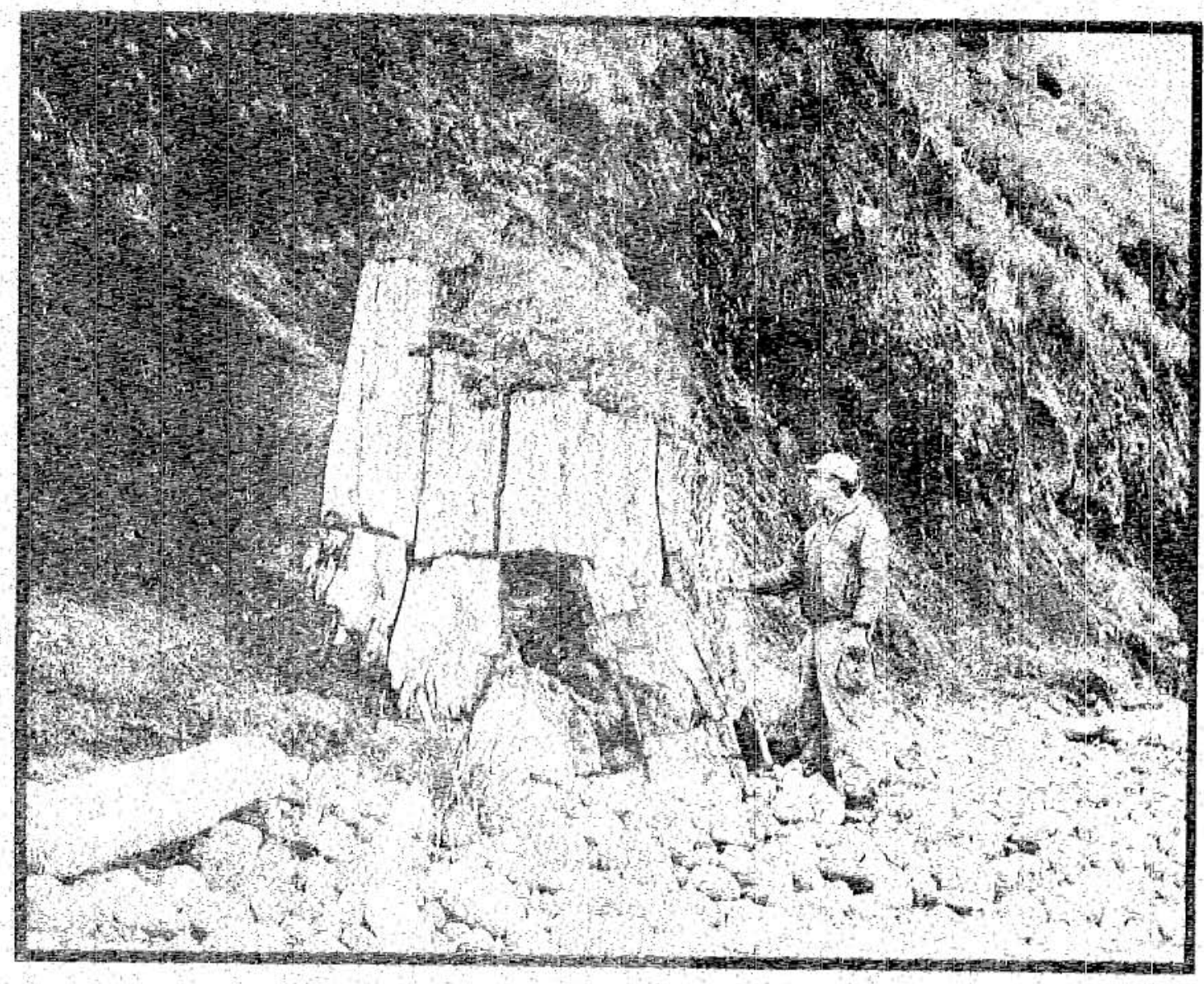

BY GILBERT R. EAKINS

SPECIAL REPORT NO. 3

\author{
DIVISION OF MINES AND GEOLOGY \\ DEPARTMENT OF NATURAL RESOURCES \\ STATE OF ALASKA \\ JULY 1970
}


STATE OF ALASKA

Keith H. Miller - Governor

DEPARTMENT OF NATURAL RESOURCES

Thomas E. Kelly - Commissioner

DIVISION OF MINES AND GEOLOGY

James A. Williams - Director

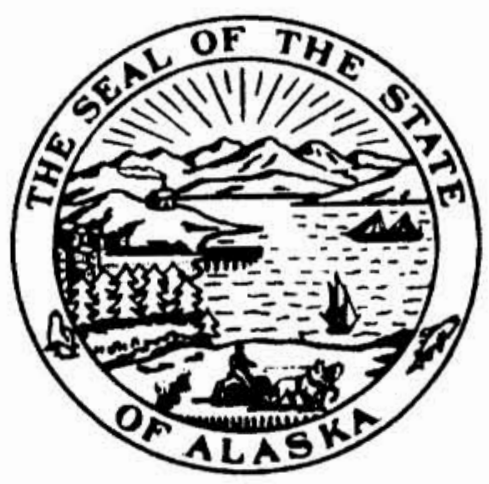

SPECIAL REPORT NO. 3

A Petrified Forest on Unga Island, Alaska

By

Gilbert R. Eakins

College, Alaska

July 1970 
INTRODUCTION . . . . . . . . . . . . . . . . . . . 1

Purpose........................... 1

Location and Access.................... . . 1

Climate and Vegetation ................. 1

Acknowledgements .................... 4

GENERAL GEOLOGY ......................... 4

Previous Mining Activity . . . . . . . . . . . . . 6

PETRIFIED FOREST . . . . . . . . . . . . . . . . . . . . . 7 7

Need for Protection . . . . . . . . . . . . . . . . 18

REFERENCES ............................. 19

I L L U S T R A T I O N S

Figure 1 Location Map - Unga Island .............. 2

2 Location of the Petrifled Forest, Shumagin Islands . . . 3

3 Southward view of the northwest coast of Unga Island . . 5

4 Fossil stump embedded in Unga Conglomerate........ 5

5 Petrified $\log 59$ feet in length ........... 8

6 Photograph of a thin section of petrified wood from Unga Island . . . . . . . . . . . . . . . 8

7 Known distribution of Sequols and Metaenquala in recent and ancient times ............... 9

8 Petrified stumps, Unga Island . . . . . . . . . 10

9 Fossil sturnps and $\log$, Unga Island ........... 11

10 Two fossil stumps exposed in wave-cut cliff, Unga Island 12

11 Fossil stump, six feet in diameter . . . . . . . . 12

12 Close-up views showing structure of fossil wood on Unga Island . . . . . . . . . . . . . . 13

13 Fossil stumps on beach, Unga Island ... . . . . . 14

14 Views showing quantity of fossil wood on shore of Unga Island . . . . . . . . . . . . . . . 15

15 Petrified logs exposed at low tide... . . . . . 16

16 Petrifled tree stumps and $\log$ sections, Unga Island . . 17 
A PETRIFIED FOREST ON UNGA ISLAND, ALASKA

by

Gilbert R. Eakins

I N T R O D U C T I O N

PURPOSL

Alaska is well known for interesting and scenic geologic features, but few people know that a petrified forest on the Alaska Peninsula rivals those in existing State and National parks in other parts of the United States. This brief report has been prepared to urge protection of a portion of the coast of Unga Island where petrified tree stumps and logs are exceptionally abundant and well preserved.

LOCATION AND ACCESS

Unga Island is in the Shumagin Island Group, on the Pacific side of the Alaska Peninsula. Petrified wood is abundant along four miles of coast on the northwest side of Unga Island. The 1sland is the largest of the Shumagin Group and is approximately 550 air miles southwest of Anchorage (figs 1 \& 2). Reeve Aleutian Airways makes scheduled flights to Sand Point, on Popof Island 14 miles east of the petrified forest. Light planes can land on the beach near either Unga Spit or Bay Point. Fishing boats from Sand Point can easily reach the area.

Unga Island is separated from the Alaska Peninsula by Unga Strait which is four miles wide between Unga Spit and Cape Allaksin. The only permanent residents of the 1sland live in the small village of Squaw Harbor, at Baralof Bay on the southeast side of the island.

\section{CLIIATE AIND VEGETATION}

The average annual rainfall on Unga Island is between 45 and 50 inches. During the winter snow covers the entire region, but by lay it has melted from the lower elevations. The weather is delightful for part of the summer, but the area is subjected to frequent rain, fog, and windstorms typical of the Alaska Peninsula and nearby islands. The average temperature from iiay through September is 49 degrees. Trees are entirely absent. 


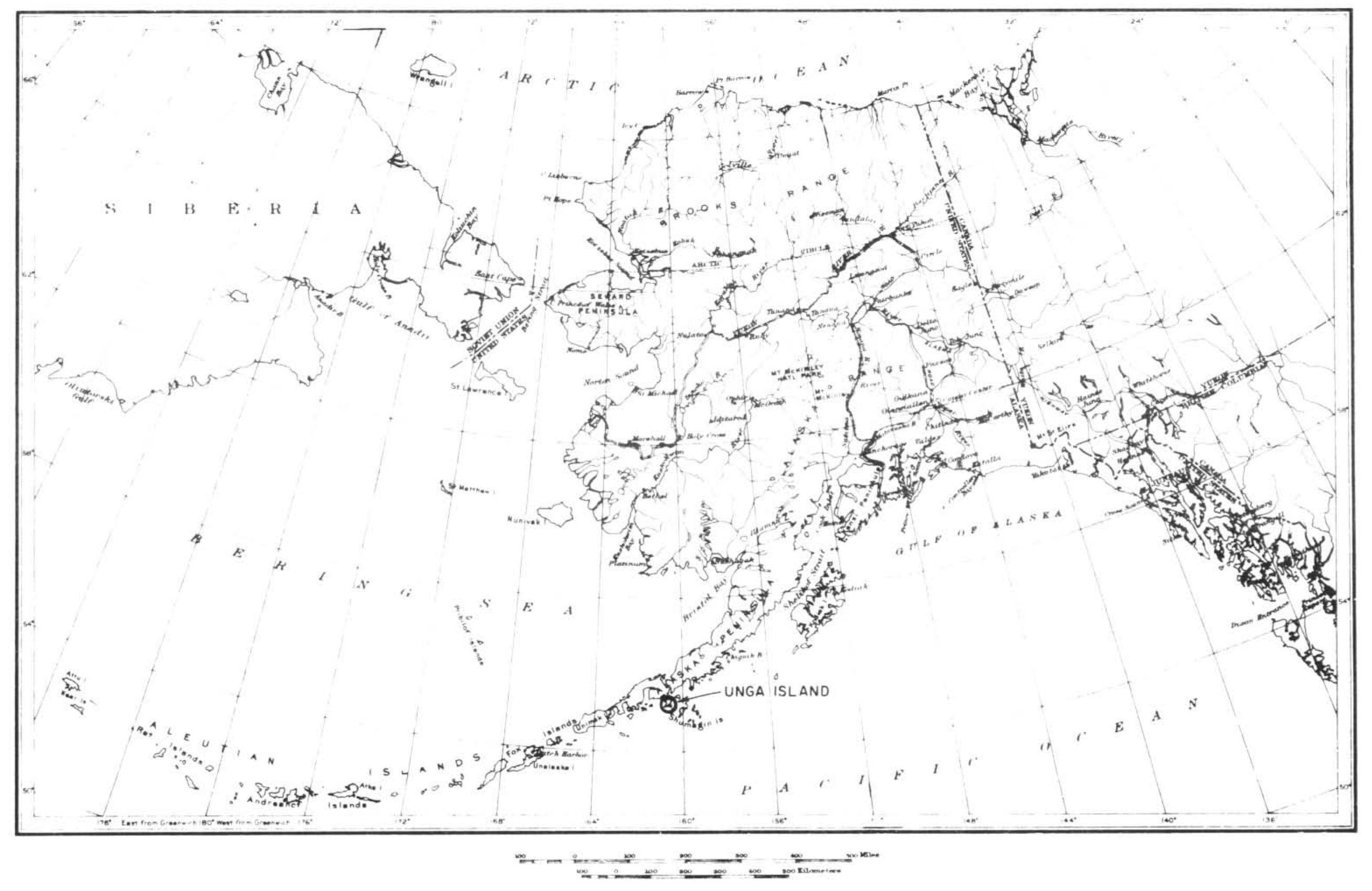

Figure 1

LOCATION MAP.UNGA ISLAND 


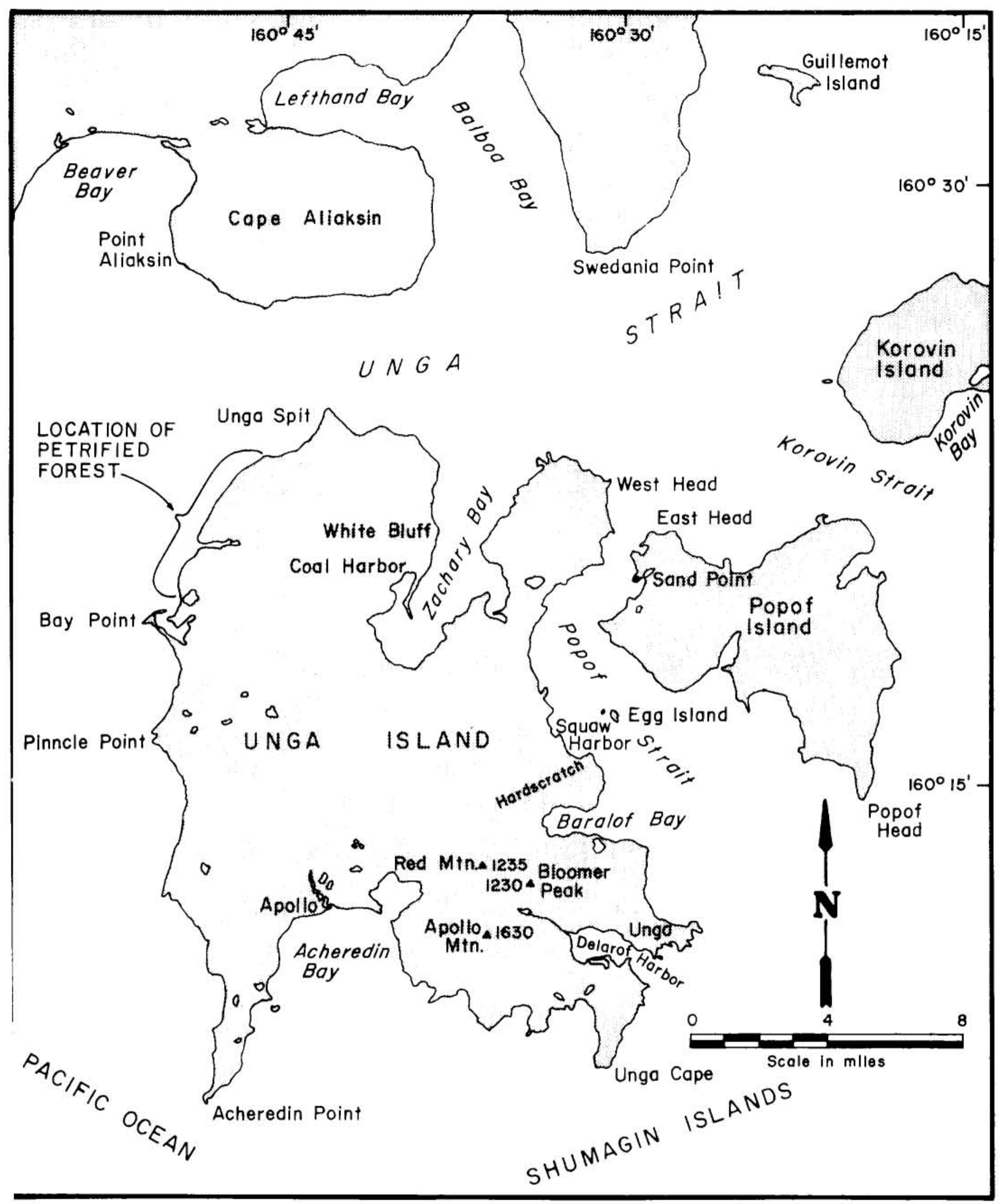

Figure 2

\section{Location of Petrified Forest Shumagin Islands, Alaska}


ACWHOWLEDGEHENTS

Andrew Gronholdt, Sand Point, Alaska, brought the Unga Island fossil wood to the writer's attention and furnished samples for identification.

Richard A. Scott, U. S. Geological Survey, venver, Colorado, identified the petrified wood and made suggestions for improving this report. Robert Pelz assisted the writer while investigating the area and furnished some of the photographs.

\author{
G E N E K A L G E O L O G Y
}

The Alaska Peninsula and nearby islands are part of a volcanic belt that extends 1000 miles fron the west side of the Cook Inlet to the west end of the Aleutian Island chain. The rugged Aleutian Range, with a number of volcanic peaks standing from 8000 to 10,000 feet above sea level, dominates the region. Several of the volcanoes are still active. Earthquakes are common in the region, and the land probably is still rising.

Unga Island formed as a result of volcanic activity, although there are no active volcanoes there at present. The eastern half of the island consists largely of andesitic and dacitic lava flows. Fragmental rocks resulting from explosive volcanic activity are common and include coarse volcanic breccia and fine-grained tuffs.

Several hundred feet of sedimentary rocks named the Unga Conglomerate member of the Bear Lake formation cover the western half of Unga Island. These rocks are younger than the lavas and overlie them in low areas. The lower part of the Unga Conglomerate consists of a series of thin, soft beds of sandstone, conglomerate, shale, and several thin beds of lignite. The upper portion of the Unga Conglomerate is a thick unit of volcanic breccia consisting of coarse fragments of volcanic rock. The fragments are mostly less than 6 inches in diameter, but range up to several feet. The petrified trees are embedded within this breccia zone. The age of these sedimentary rocks is Miocene; they were deposited 11 to 25 million years ago.

The eastern side of Unga Island is mountainous. The highest peak is 2030 feet. The western portion is more subdued, and the northwest part consists of low, rolling hills and grassland less than 400 feet above sea level ( $f i g$ 3). The topography of the entire island has been affected by glaciers which scoured the surface during the last ice age. Unga Island has risen about 100 feet since Pleistocene time. The lower, flatter parts of the islend are ol.d sea terraces. 


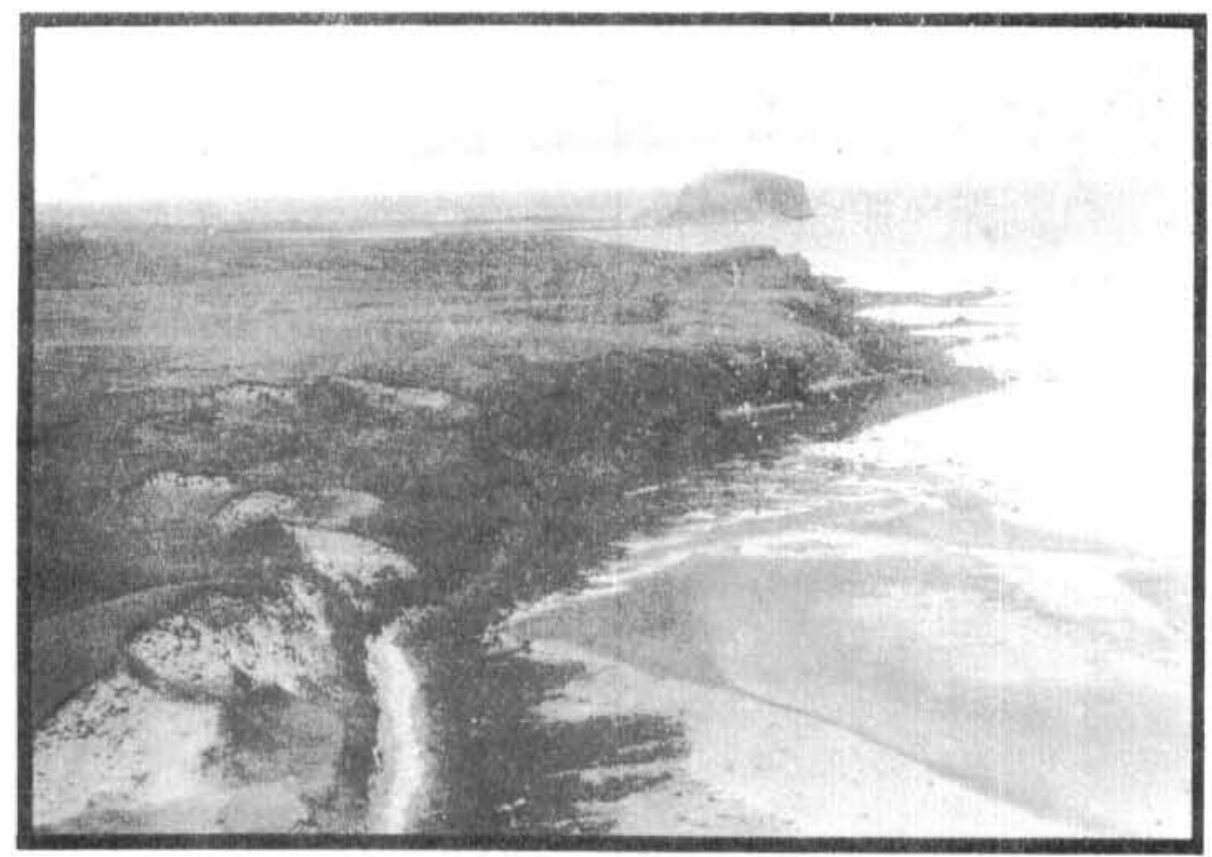

Figure 3. Southward view of the northwest coast of Unga Island. The protruding feature in the background is a volcanic plug called Bay Point.

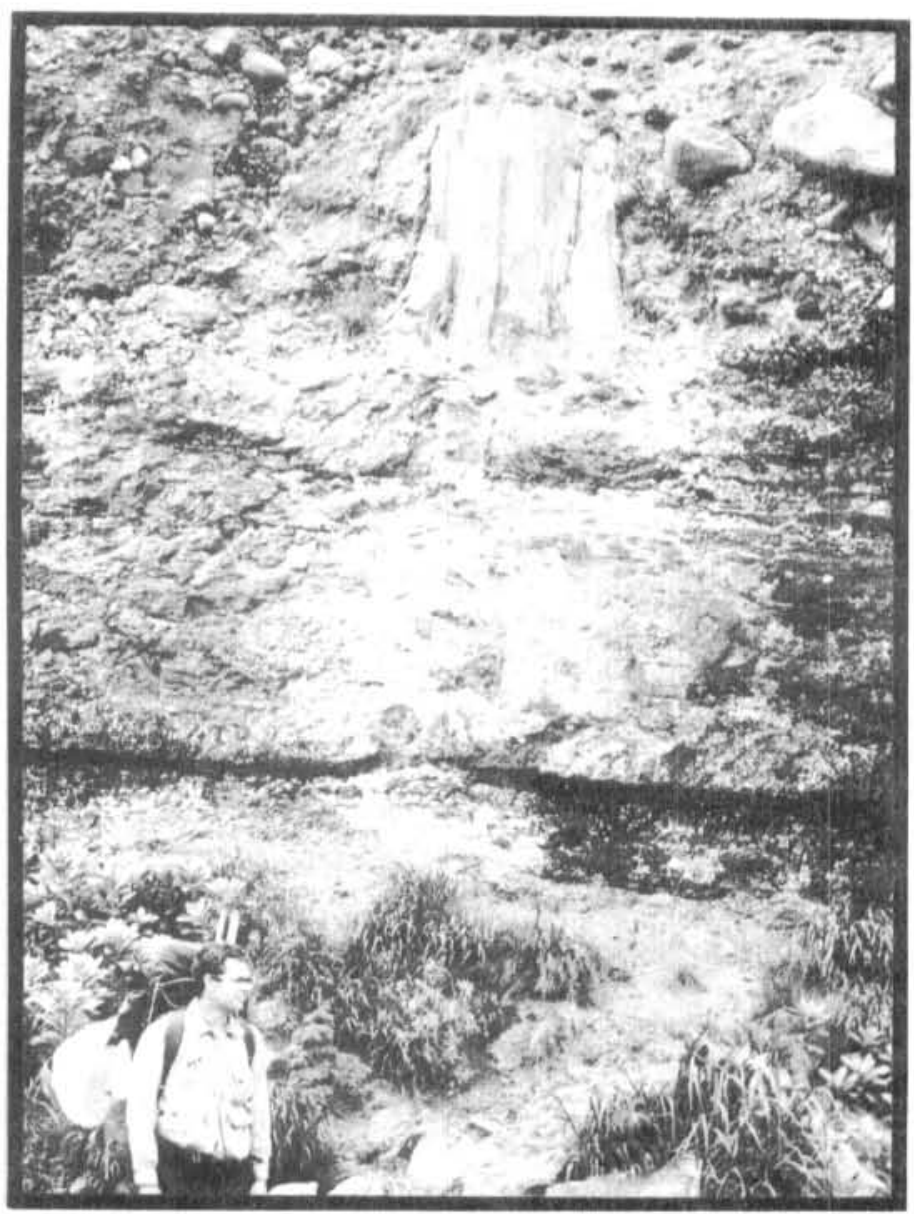

Figure 4. Fossil stump embedded in Unga Conglomerate. Upper portion in the plate is a coarse volcanic breccia or agglomerate; the lower part consists of shale beds. 
Much of the coastline of Unga Island, especlally along the southeastern side, is very steep and rugged. Wave action has created abrupt cliffs as much as several hundred feet high, and sea stacks, caves, and arches are common. Cliffs are less spectacular on the western side where the softer Unga Conglomerate is exposed. This facilitates access to the petrified forest area. In the bluff along the northwest coast, the shales and sandstones of the lower portion of the Unga Conglomerate can be seen underlying the coarser breccia in which trees are embedded ( $f i g 4)$.

\section{PREVIOUS MINING ACTIVITY}

Two gold mines were operated from 1336 until about 1912 near the head of Delarof Bay on the south side of Unga Island (Atwood, 1911, Lartine, 1968). They are estimated to have yielded approximately three million dollars (Vlartine, $p$ 8). The long-abandoned mining camp of Apollo once had a population of 150 (Orth, 1967). Ruins of a large stamp mill are all that remain there now. Near the Apollo mine camp, at the nouth of Delarof Bay, are the remnants of the village of Unga, which had a population of 313 (Orth, 1967) in 1950.

Low grade coal was mined intermittently between 1871 and 1912 from the west side of Zachary Bay on the north end of the 1sland (Atwood, 1911; Orth, 1967). A settlement there was called Coal Harbor, but nothing remains.

011 shows have been reported from exploration wells at several locations along the Alaska Peninsula. If the current oll boom continues in Alaska, it is quite possible that the entire offshore area from Cook Inlet to the Shumagin Islands will eventually be explored. 
Petrified logs and stumps have been uncovered by wave action along the northwest coast of Unga Island over a distance of about four miles. The sea cliffs of interest begin about two miles south of Unga Spit and extend to Bay Point. They are from 50 to 100 feet high. Tree remnants are visible in the bluff along the shore, on the beach, and on the tideland (figs 8 - 16). It has been calculated that petrified wood is fairly evenly distributed over 150 acres of beach area (A. Gronholdt, written communication, April 1970). Viany stumps are still in upright positions. The best specimens are large stumps about half way between Unga Spit and Bay Point. Several measure between four and nine feet in diameter. At some points along the shore, especially at low tide, dozens of fossil log sections are visible. The largest log can be seen only at low tide. This specimen is nine feet in diameter and 46 feet long ( $f i g$ ). Including broken segments, the $\log$ is 59 feet long.

Petrification of plants is not fully understood, but one requirement is that the plants must be buried rapidly before they decay. The petrification is believed to be a slow process whereby circulating ground water carrying silica in solution infiltrates the woody tissue and the silica is deposited there. Undecayed organic matter forming the original plant tissues thus becomes imbedded in silica and preserved for long periods of time.

Burial of the ancient forest at Unga Island appears to have been caused by the sudden deposition of volcanic breccia derived from nearby volcanic centers. The trees have been preserved by silicification. Silica apparently was dissolved from the volcanic rocks by running water and redeposited as chalcedony in the burled trees. The original grain of the wood generally is very well preserved. An example is shown in figure 6, although this specimen is a ring porous, dicotyledonous type of wood rather than the coniferous wood most prevalent at Unga Island. Litele of the material is agatized and is not suitable for lapidary work. The colors of the fossil wood are black, yellow, and gray. The black pieces look as though they have been charred.

Some of the trees have been identified as belonging to the genus Sequoia or Metasequoia, although it is almost impossible to distinguish the two from the wood alone (R. A. Scott, written communication, 1970). No leaves or cones were found. While both genera are coniferous, Metasequoia sheds its needles in winter and Sequoia is evergreen. In fairly recent years Metasequoia received considerable publicity from its discovery as a "Iiving fossil". This tree, previously thought to have become extinct about 20 million years ago, was discovered growing in a small area in the Szechuan region of China. Chaney (1948) has described this find.

Both genera were widespread over the Northern Hemisphere in ancient time from as far south as the western conterminous United States to above the Arctic Circle ( $f i g$ ?). Growth apparently was restricted to valleys and areas of low to moderate elevations. The Milocene forest on Unga Island 


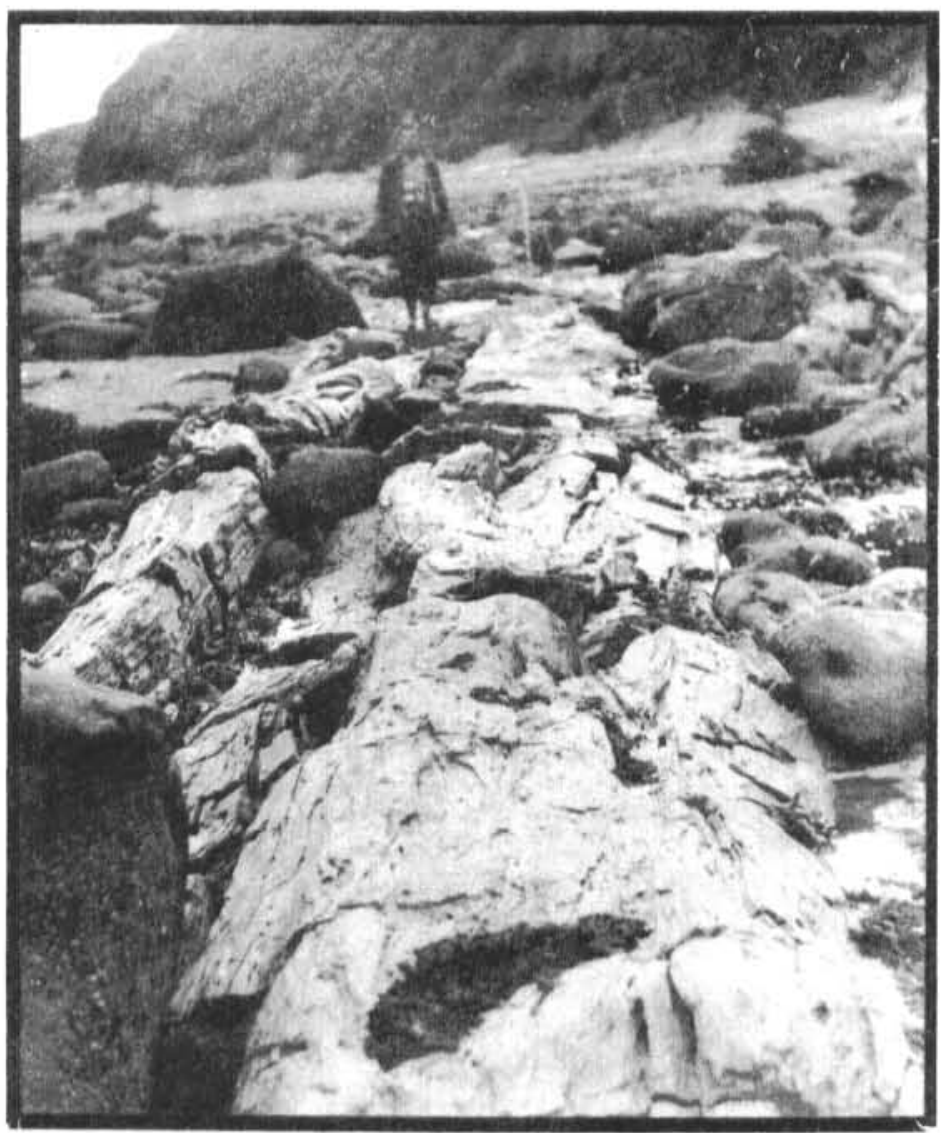

Figure 5. Petrified $\log 59$ feet in length.

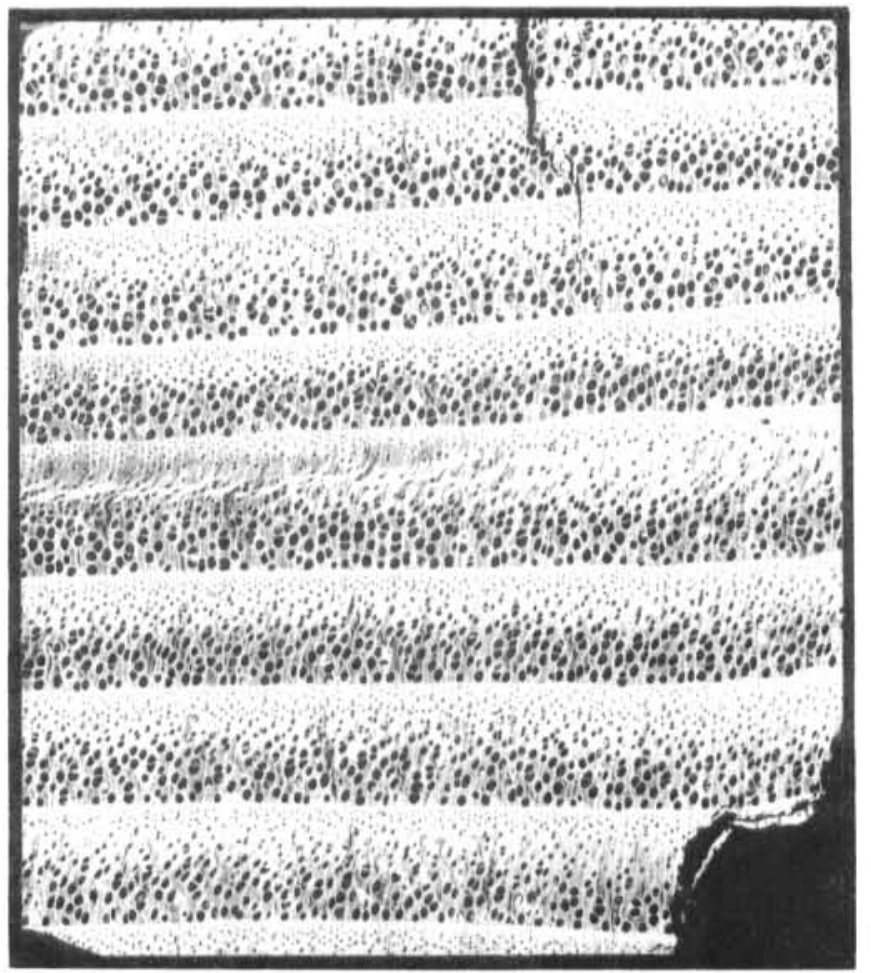

Figure 6. Photograph of a thin section of petrified wood from Unga Island. 


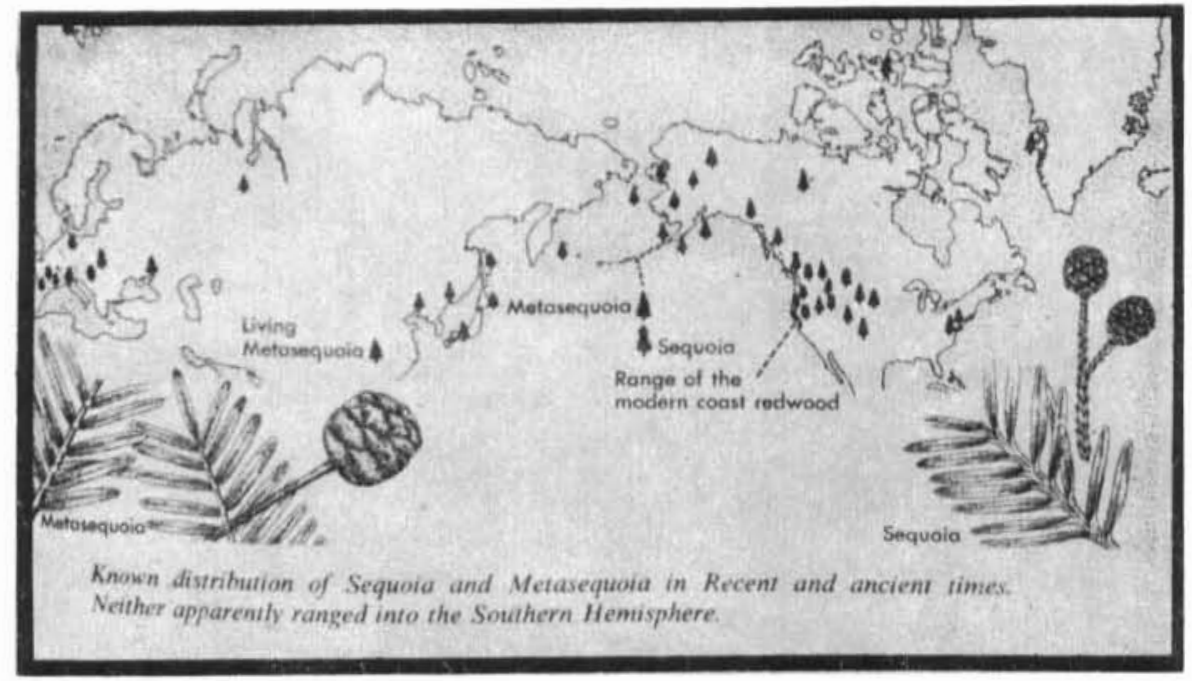

Figure 7. From "The Fossil Book", p 385, by Carol Lane Fenton and Mildred Adams Fenton, 1958. Reproduced by permission of Doubleday and Company, Inc. 

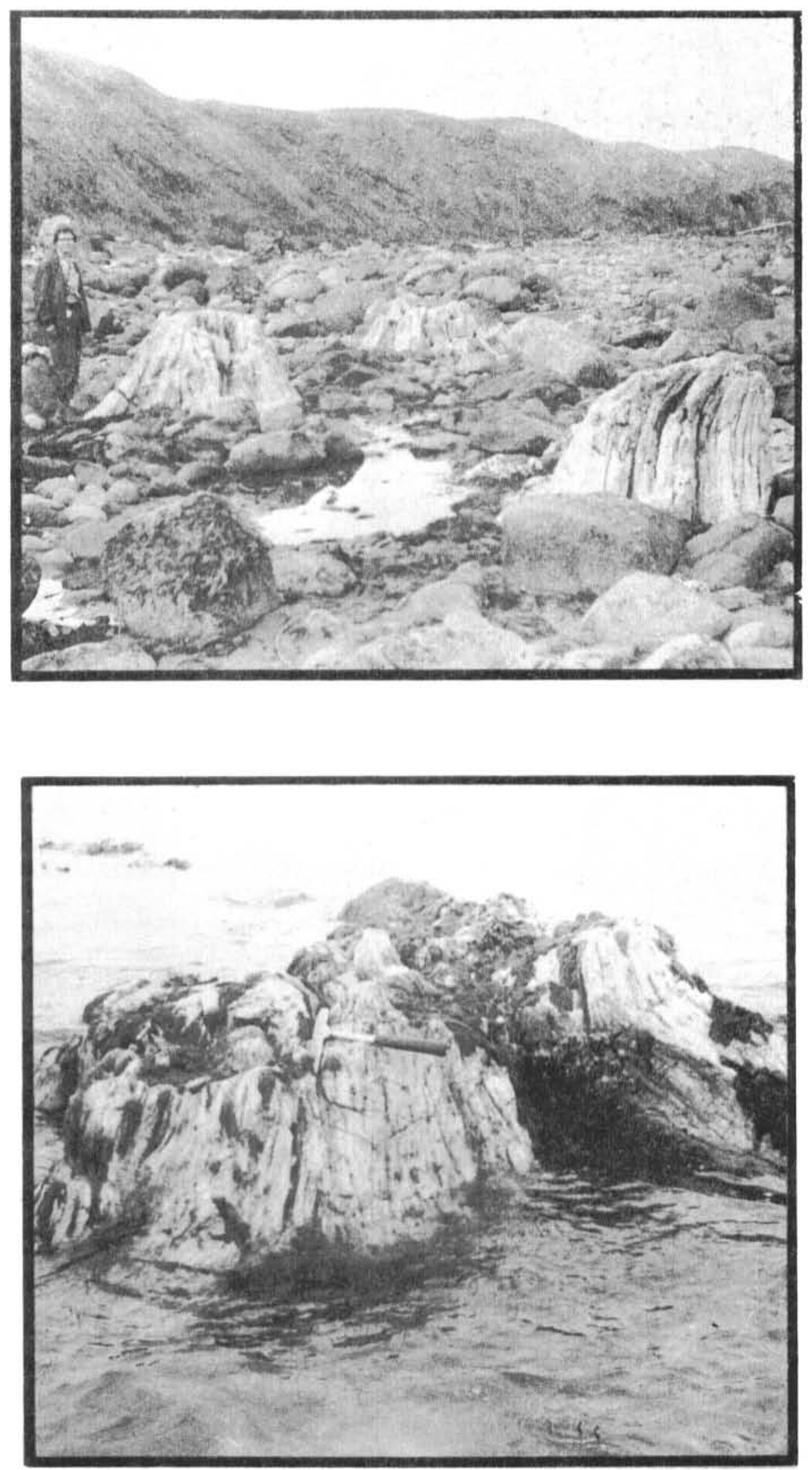

Figure 8. Petrified stumps, Unga Island. 

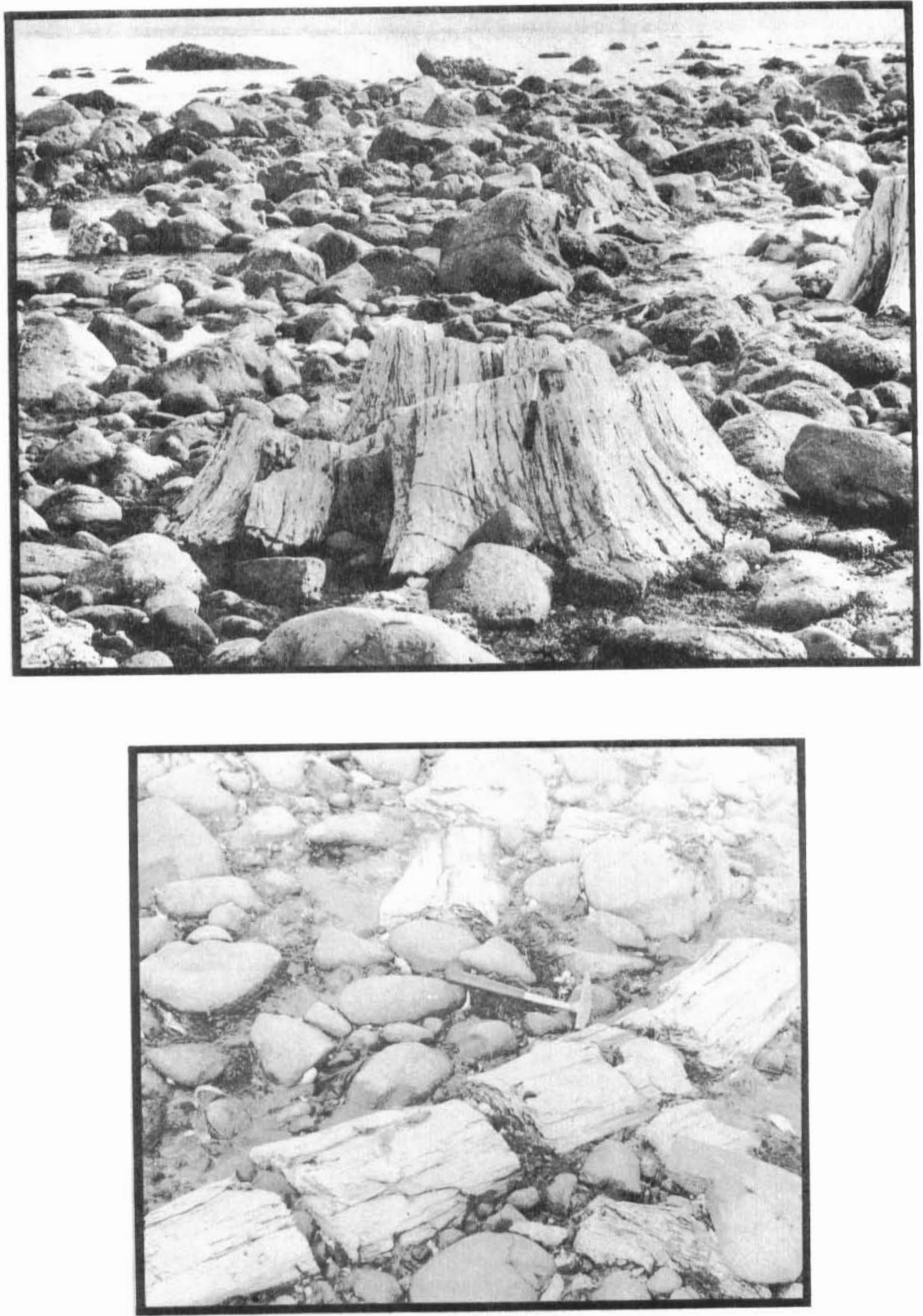

Figure 9. Fossil stumps and logs, Unga Island. 


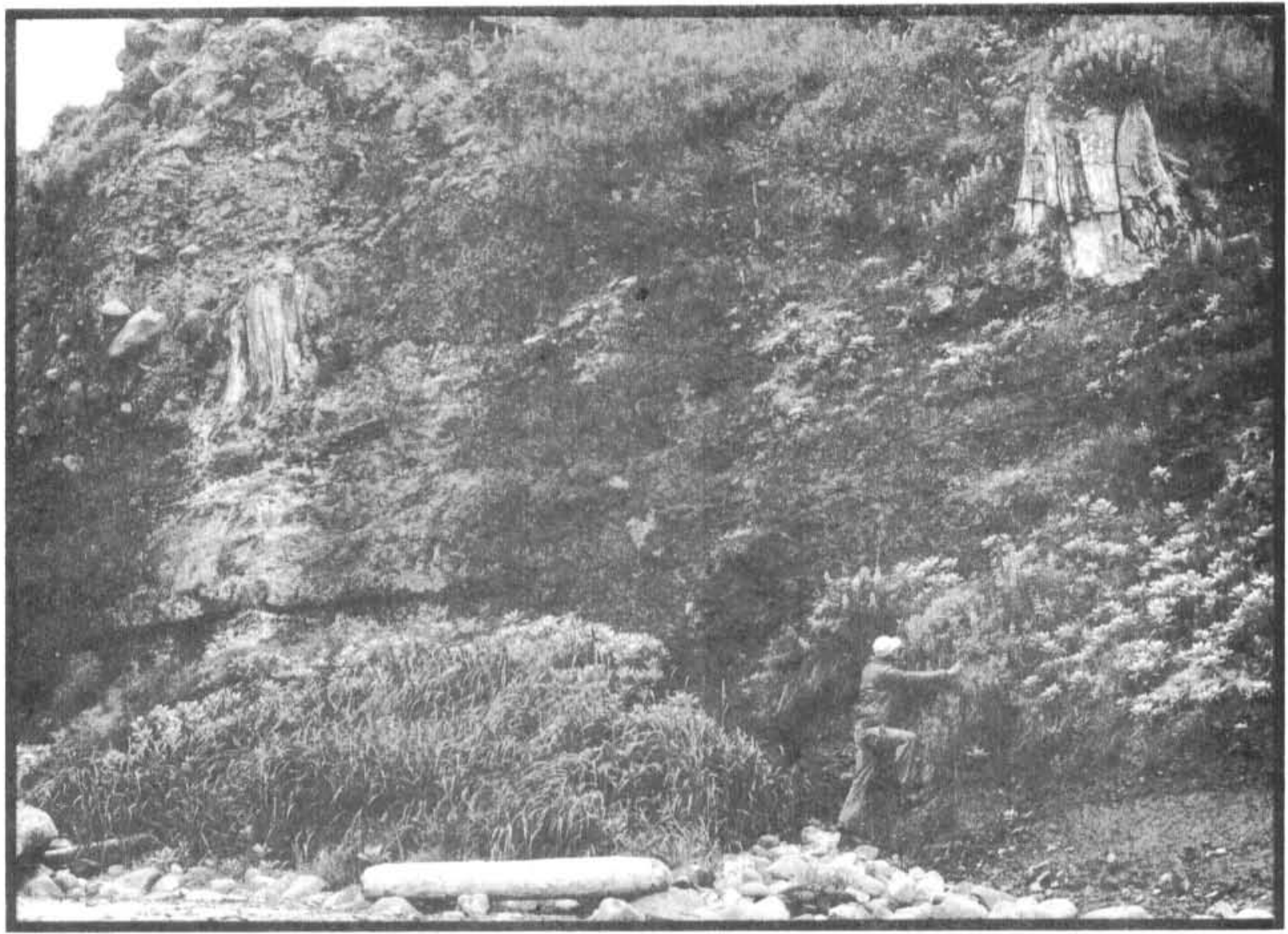

Figure 10. Two fossil stumps exposed in wave-cut cliff, Unga Island.

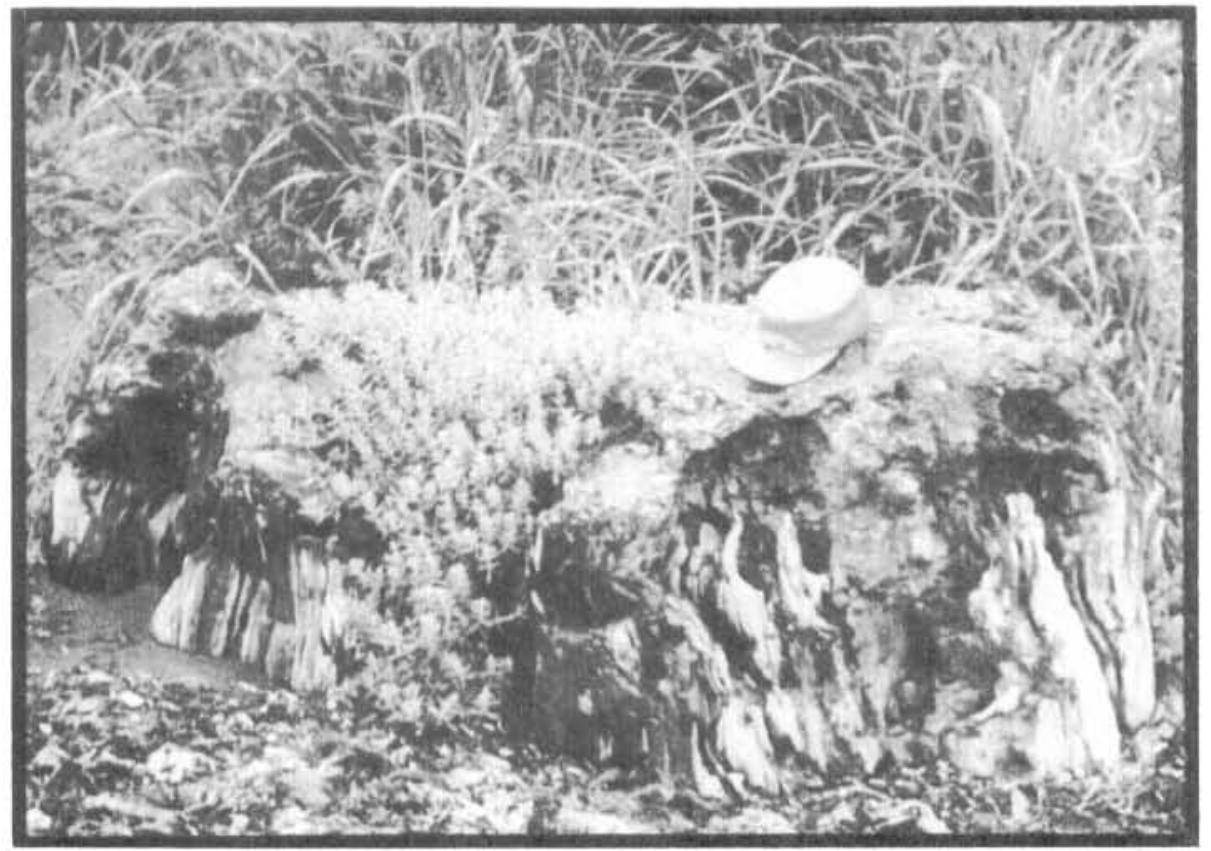

Figure 11. Fossil stump, six feet in diameter. 

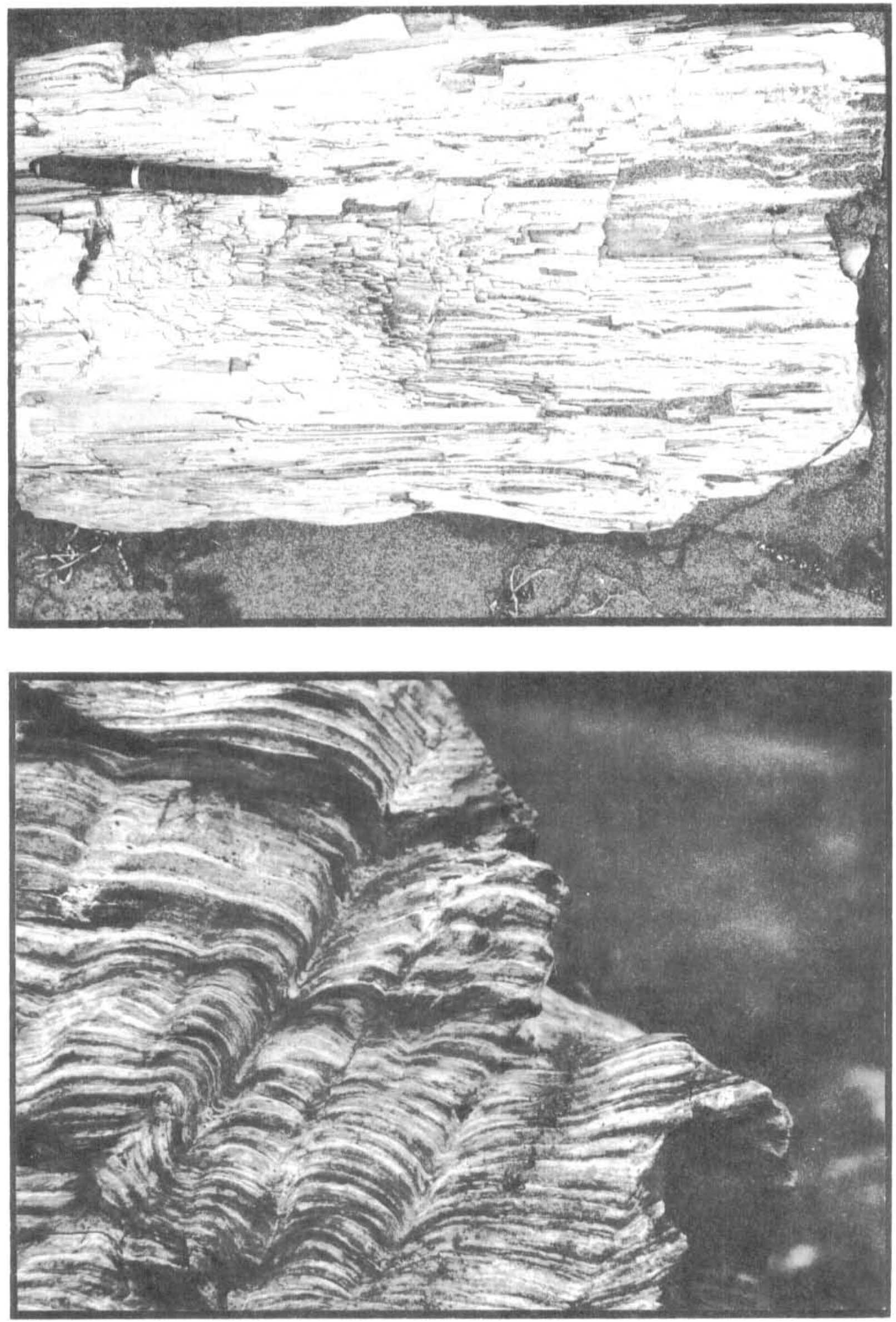

Figure 12. Close-up views showing structure of fossil wood on Unga Island. 

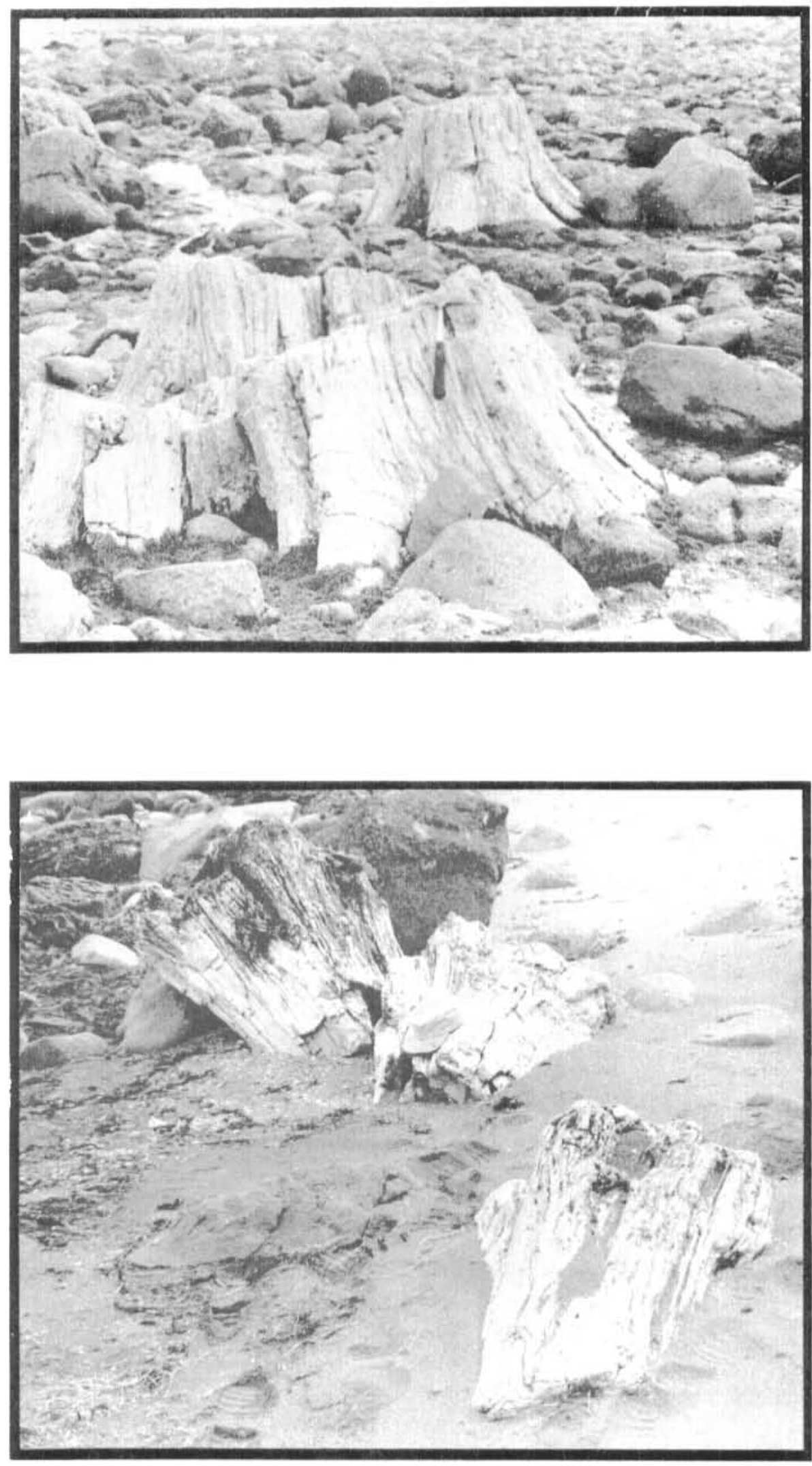

Figure 13. Fossil stumps on beach, Unga Island. 

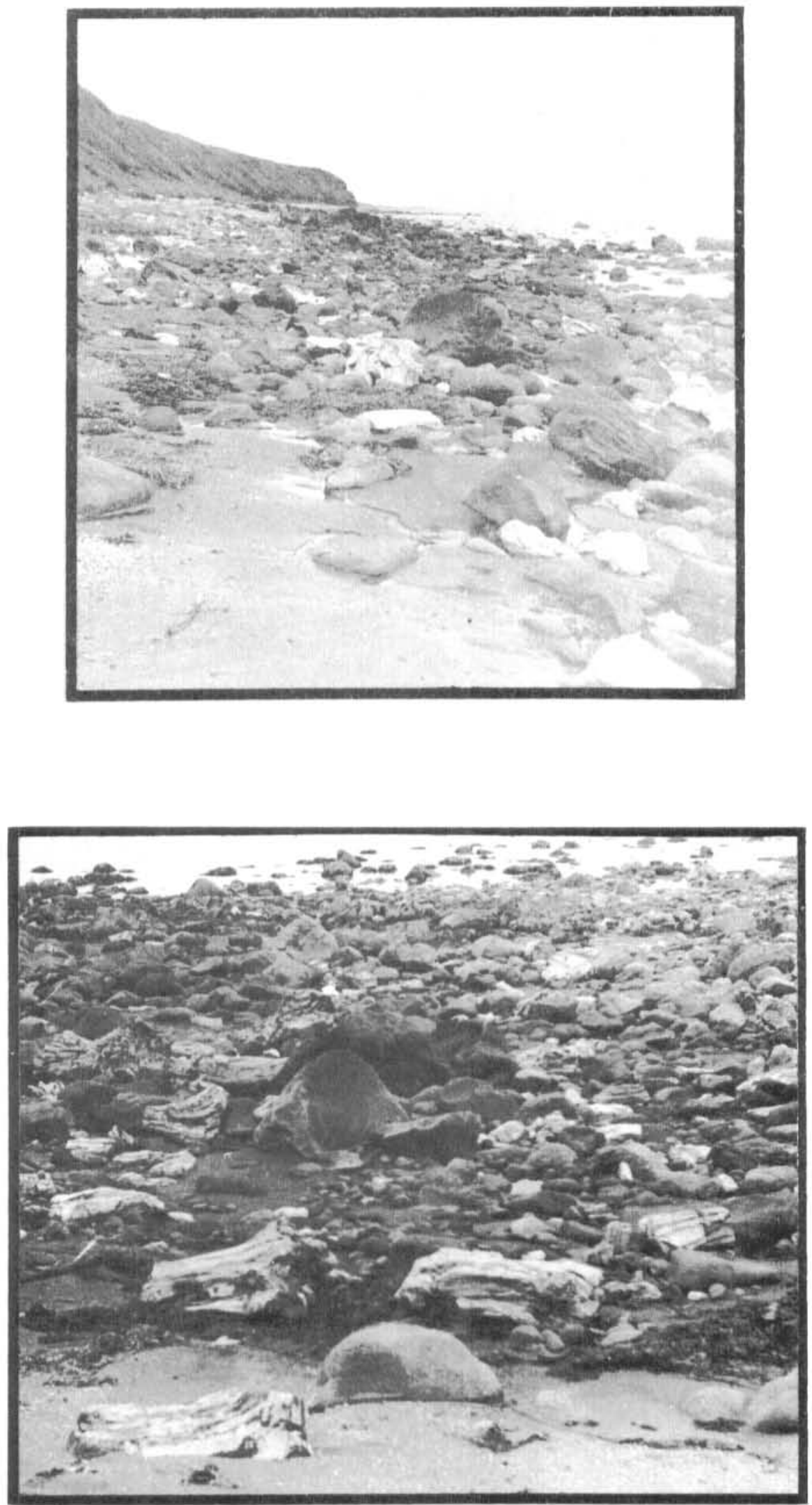

Figure 14. Views showing quantity of fossil wood on shore of Unga Island. All light-colored material is fossil wood. 

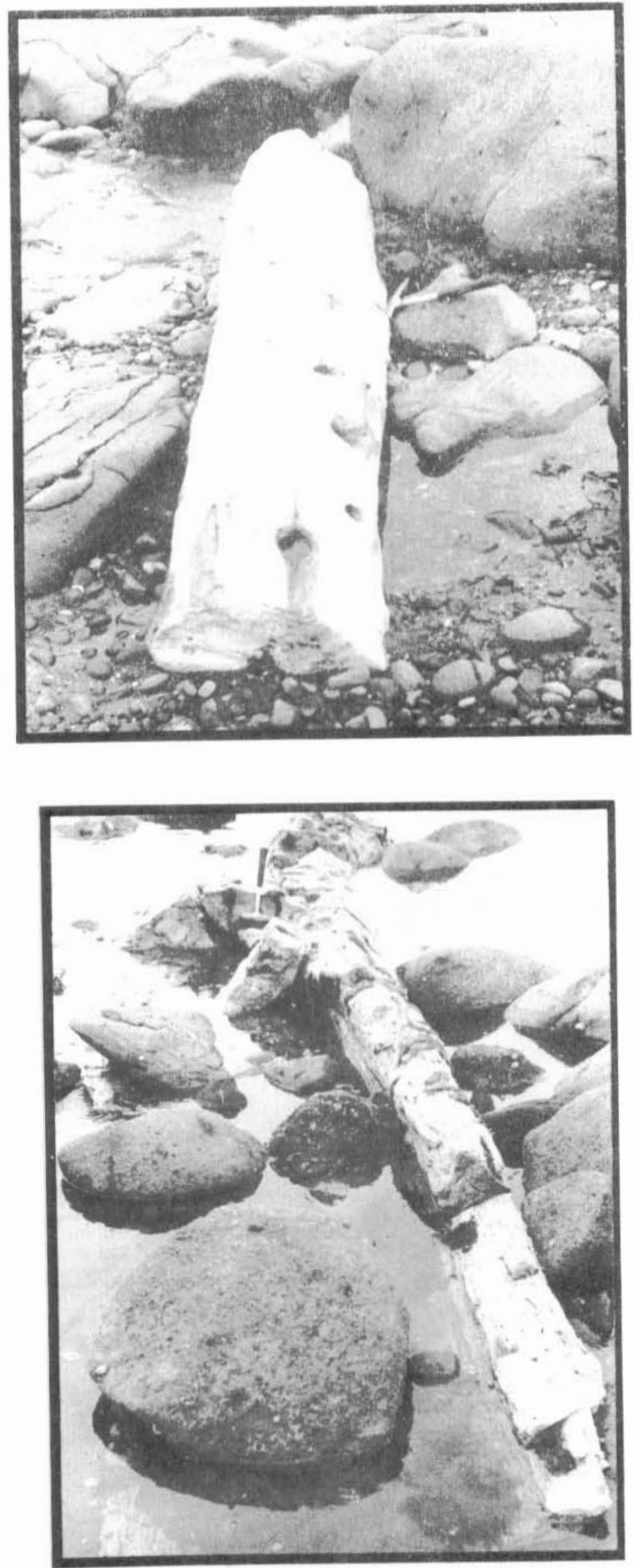

Figure 15. Petrified logs exposed of low tide. 

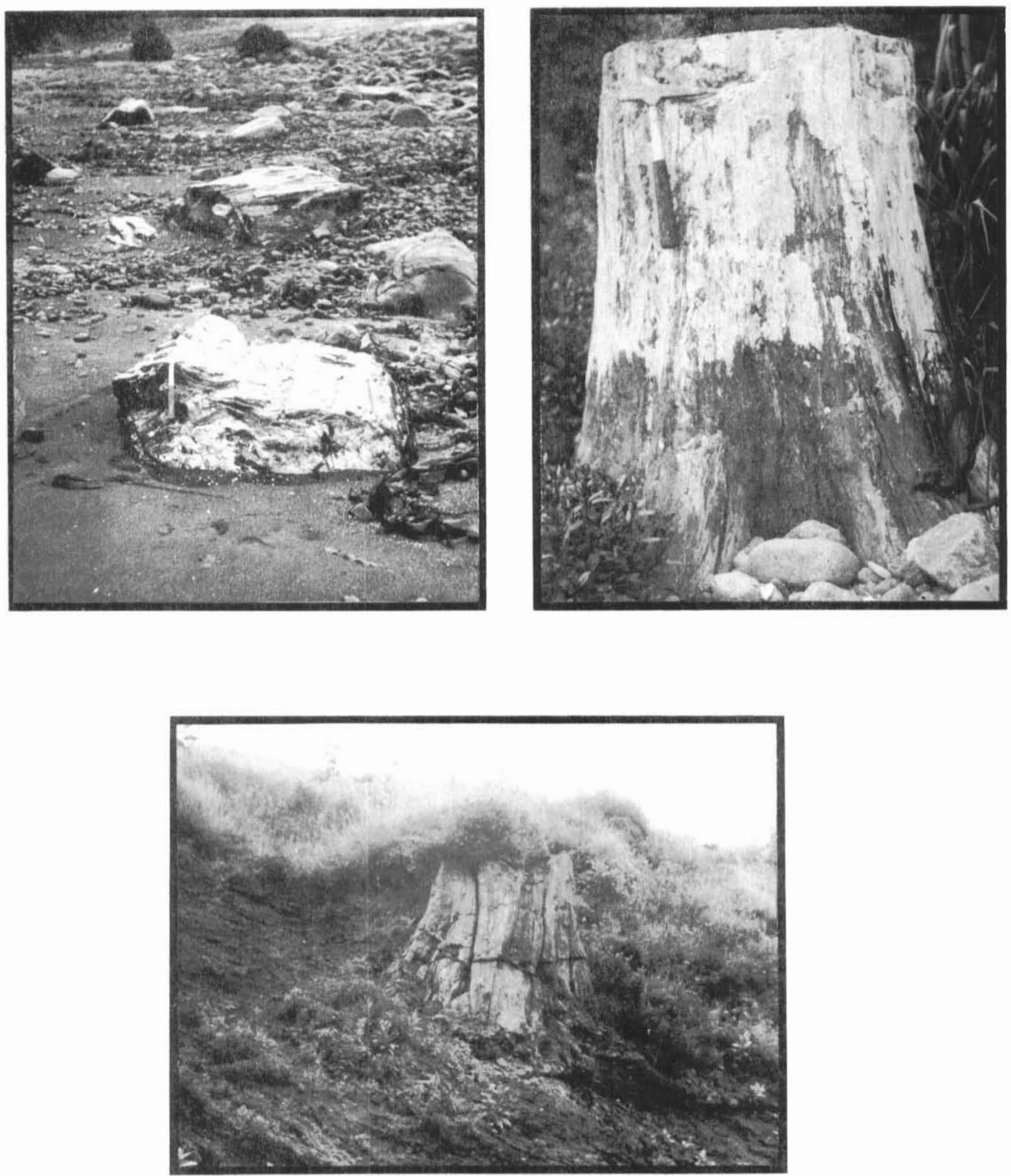

Figure 16. Petrified tree stumps and $\log$ sections, Unga Island. 
was probably located in a low, humid area, possibly a flood plain, favorable to the growth of giant trees. Temperatures were moderate, and seldom fell below freezing. As the climate became dryer and cooler, Sequola was restricted southward to Oregon, northern California and Japan, surviving only in the New World. Metasequola was less adaptable and survived only in the small area in central China.

Scott has expressed his willingness to formally name and describe the fossil wood on Unga Island. The writer hopes that he will be able to do so, thereby adding to the information on this interesting Alaskan occurrence.

\section{NEED FOR PROTECTION}

As tourism increases and people search farther for areas that are still in their natural state, the unspoiled Shumagin Islands undoubtedly will be appreciated more and more. Although the petrified forest of Unga Island is off the beaten path, it can be reached easily by air or by water from the nearby village of Sand Point on Popof Island. Sand Point is an exceptionally clean and colorful village characterized by fish and crab canneries and a harbor for small boats. Enroute to this area visitors might also enjoy archeological sites, the Imposing volcanoes and waterfalls of the Aleutian Range, and big game hunting on the mainland.

The petrified forest on Unga Island must be protected now, if it is to be enjoyed by future generations. Three attempts were made recently to remove large quantities of fossil material by barge and boat for marketing in Seattle. Only the efforts of Andrew Gronholdt of Sand Point limited this activity. Another example of excessive collecting occurred when a group of "rockhounds" removed 1200 pounds of agate during a single visit to one of the islands in the Shumagin group. It is recommended herein that the State of Alaska set aside the best exposed parts of the petrified forest as a State Park or Wilderness Area for all to enjoy before it is destroyed. 
Alaska Sportsman, The, May, 1957, p 28. (Photograph of fossil stump on Unga Island). on Unga Island).

, Feb., 1969, p 33. (Photograph of fossil stumps

Atwood, Wallace W., 1911, Geology and Mineral Resources of Parts of the Alaska Peninsula: U. S. Geol. Survey Bull. 467, p 21, 126, 127.

Burk, C. A., 1965, Geology of the Alaska Peninsula, Island Arc and Continental hargin: Geol. Soc. America Memolr 99.

Butcher, Helen, 1967, Rockhounds and Octop1: The Alaska Sportsman, May, 1967, p 31. (An Article About the Experiences of a Group of Rockhounds During Their Visit to Sand Point).

Chaney, Ralph W., 1943, The Bearing of the Living Metasequola on Problems of Tertiary Paleobotany: Proceedings of the National Academy of Sciences, Vo1 34, ilo 11, p 503-515.

Fenton, C. L. and Fenton, M. A., 1958, The Fossil Book, p 384-386.

Martine, Mrs. R. B., 1968, Apollo: The Alaska Sportsman, May, 1968, p 8..... (An Article on the History of the Apollo Mine and Life on Unga Island During Those Days).

Orth, Donald J., 1967. Dictionary of Alaska Place Names. U. S. Geol. Survey Prof. Paper 567.

Smith, Philip S., 1936, The Tertiary Floras of Alaska: U. S. Geol. Survey Prof. Paper 182.

Wolf, Jack A., 1969, Paleogene Floras from the Gulf of Alsaks Regton: U. S. Geol. Survey Open-File Report. 